\title{
ON MODIFIED METHOD OF MULTISTEP COORDINATE DESCENT FOR OPTIMAL CONTROL PROBLEM FOR SEMILINEAR SOBOLEV-TYPE MODEL
}

\author{
N.A. Manakova, South Ural State University, Chelyabinsk, Russian Federation, \\ manakovana@susu.ru
}

\begin{abstract}
The paper describes a numerical method for solving the optimal control problem for a semilinear model of Sobolev-type. The method is based on both the modified projection Galerkin method and the method of multistep coordinate descent with memory. New numerical methods for solving nonlinear optimal control problems are need, because there exists a large number of applications and it is difficult to find their analytical solutions. We consider mathematical model of regulating potential distribution of speed of the filtered liquid free surface motion. In order to numerically investigate the mathematical model, we use the sufficient conditions for the existence of an optimal control by solutions of Showalter - Sidorov problem for semilinear Sobolev type equation with $s$-monotone and $p$-coercive operator. We present the results of computational experiment that demonstrate the work of the proposed numerical method.
\end{abstract}

Keywords: semilinear Sobolev-type equation; optimal control problem; numerical solution; Galerkin method; method of multistep coordinate descent.

\section{Introduction}

A study of different technological processes and objects leads to the study of initial problems for semilinear nonclassical models of mathematical physics. For different values of model parameters, there are initial-boundary problems for partial differential equations and systems of partial differential equations, which are not solved by derivative with respect to time. For the first time, R.E. Showalter [1] proposed to call such equations Sobolev-type equations [1-6]. Many papers [2,4,6-9] are devoted to questions of analytical and quality study of initial (multipoint initial-final) problems for linear and semilinear Sobolev-type models.

A study of the possibility to controll by an external influence, which allows to achieve the desired result by minimum cost, is of undoubted theoretical and practical interest. A large class of applied control problems can be investigated in the framework of the optimal control problem

$$
J(x, u) \rightarrow \text { inf, } u \in U_{a d},
$$

where pairs $(x, u)$ satisfy Showalter - Sidorov problem for semilinear Sobolev-type equation

$$
L \dot{x}+M(x)=u, \quad L\left(x(0)-x_{0}\right)=0, \operatorname{ker} L \neq\{0\} .
$$

Here $J(x, u)$ is a specially constructed objective functional; $U_{a d}$ is a closed and convex set in the space of controls $U$. The optimal control problems for linear Sobolev-type equations of the first and high orders with Cauchy or Showalter - Sidorov conditions are studied in [10-14]. Development of the optimal control theory for linear Sobolev-type equations allows not only analytically and numerically solve control problems for applied models, but also to develop the theory of optimal measurements $[15,16]$. For the first time, A.L. Shestakov 
and G.A. Sviridyuk [15] propose to apply methods of optimal control in order to solve problems of dynamically distorted signals restoration.

The main difficulties of optimal control problem (1), (2) study are non-linear structure and degeneracy of the equation. The initial Showalter - Sidorov condition is considered in the case of Sobolev-type equations. It allows to avoid both the phenomenon of nonuniqueness of Cauchy problem solution and the need to choose the initial data from not all space, but only from a subset [17]. New numerical methods for solving nonlinear optimal control problems are actual, because there exists a large number of applications and it is difficult to find their analytical solutions. Note the great interest in the study of optimal control problems. Nevertheless, numerical methods for solution of optimal control problem remain poorly investigated.

Consider Showalter - Sidorov problem (2) solution with a self-adjoint, nonnegative defined, fredholm operator $L$ and $s$-monotone and $p$-coercive operator $M$. An existence of such solution is investigated [11] on the base of the phase space method [18] and the classical methods of monotonicity and compactness [19]. Approximate solutions of problem (1), (2) are constructed by Galerkin projection method [20]. Such method successfully established itself in the analytical and numerical studies of initial boundary problems for Sobolev-type equations [20-22] and allowed to take into account the phenomenon of the equation degeneracy, when approximate solutions are constructed. According to Galerkin method, the coefficients of the approximate solution of problem (1), (2)

$$
x^{m}(s, t)=\sum_{i=1}^{m} a_{i}(t) \varphi_{i}(s), u^{m}(s, t)=\sum_{i=1}^{m} u_{i}(t) \varphi_{i}(s)
$$

can be found from the system of nonlinear differential-algebraic equations

$$
\left\langle L x_{t}^{m}, \varphi_{i}\right\rangle+\left\langle M\left(x^{m}\right), \varphi_{i}\right\rangle=\left\langle u, \varphi_{i}\right\rangle, i=1, \ldots, m,
$$

with initial Showalter - Sidorov condition

$$
\left\langle L\left(x^{m}(0)-x_{0}\right), \varphi_{i}\right\rangle=0, i=1, \ldots, m .
$$

Then objective functional $J$ depends on unknown functions of state $x^{m}$ and control $u^{m}$. We consider state equations (3) with initial conditions (4) as a restriction on the problem (1). The result is the problem to minimize functional $J\left(x^{m}, u^{m}\right)$ on the set of admissible pairs of controls and states. The problem is solved by the method of multistep coordinate descent with memory. Papers [23,24] propose to use such method in order to numerically solve the control problems for Leontief type equations (i.e., for linear finite Sobolev-type equations). The article considers the modification of such algorithm in the case of nonlinear systems of differential-algebraic equations. It allows to find approximate solutions of problem (1), (2). In [25] we propose an algorithm to find the numerical solution of optimal control problem for semilinear Sobolev-type equations. The algorithm is based on both Galerkin method and the decomposition method. However, the numerical method allows to find solution of optimal control problem (1), (2) in the case, when operator $M$ has a linear component. Numerical method constructed in the article allows to avoid such restriction and to solve a wider class of problems.

The proposed algorithm of numerical method is illustrated by optimal control problem (1) for the filter model [26]

$$
(\lambda-\Delta) x_{t}-\alpha \Delta\left(|x|^{p-2} x\right)=u, p \geq 2
$$




$$
x(s, t)=0,(s, t) \in \partial \Omega \times(0, T)
$$

with initial Showalter - Sidorov condition

$$
(\lambda-\Delta)\left(x(s, 0)-x_{0}(s)\right)=0 .
$$

Equation (5) was first obtained by E.S. Dzektser [27]. Here unknown function $x=x(s, t)$ correspods to a potential of speed of the filtered liquid free surface motion; parameters $\alpha \in \mathbb{R}_{+}, \lambda \in \mathbb{R}$ characterize the environment, where a value of parameter $\lambda$ can be negative; free term $u=u(s, t)$ corresponds to an external load, i.e. to source and drain of liquid. The physical sense of optimal control problem for the model is effective regulation of filtered liquid flows in the layer.

\section{Optimal Control Problem}

Let $H=(H,<\cdot, \cdot>)$ be a real separable Hilbert space identified with its conjugate; $\left(A, A^{*}\right)$ and $\left(B, B^{*}\right)$ be dual (with respect to duality $\left.<\cdot, \cdot>\right)$ pairs of reflexive Banach spaces, where embeddings

$$
B \subset A \subset H \subset A^{*} \subset B^{*}
$$

are dense and continuous. Let $L \in \mathcal{L}\left(A ; A^{*}\right)$ be linear, continuous, self-adjoint, nonnegative defined, fredholm operator such that its orthonormal (in the sense of $H$ ) set of eigenvectors $\left\{\varphi_{k}\right\}$ is a basis in space $A$, and $M \in C^{r}\left(B ; B^{*}\right), \quad r \geq 1$, is $s$-monotone and $p$-coercive operator, where $p \geq 2$ [11], with symmetrical Frechet derivative. Construct control space $U=L_{q}\left(0, T ; A^{*}\right), \frac{1}{p}+\frac{1}{q}=1$, and define a non-empty closed convex set $U_{a d}$ in space $U$. Consider optimal control problem (1), (2) and define an objective functional as follows:

$$
J(x, u)=\alpha \int_{0}^{T}\left\|x(t)-z_{d}(t)\right\|_{B}^{p} d t+\beta \int_{0}^{T}\|u(t)\|_{B^{*}}^{q} d t, \alpha+\beta=1,
$$

where $z_{d}=z_{d}(s, t)$ is a desired state. Consider a set

$$
\operatorname{coim} L=\{x \in A:\langle x, \varphi\rangle=0 \forall \varphi \in \operatorname{ker} L \backslash\{0\}\} .
$$

Construct a space

$$
X=\left\{x \mid x \in L_{\infty}(0, T ; \operatorname{coim} L) \cap L_{p}(0, T ; B), \frac{d x}{d t} \in L_{2}(0, T ; \operatorname{coim} L)\right\}
$$

Due to embeddings (8), system $\left\{\varphi_{k}\right\}$ of operator $L$ eigenvectors is total in $B$. Therefore, construct Galerkin approximations of problem (2) solutions in the form

$$
x^{m}(t)=\sum_{k=1}^{m} a_{k}(t) \varphi_{k}, \quad m>\operatorname{dim} \operatorname{ker} L,
$$

where coefficients $a_{k}=a_{k}(t), k=1, \ldots, m$, are defined by problem (3), (4).

Definition 1. A weak generalized solution of problem (2) is a vector function $x \in X$, which satisfy conditions

$$
\int_{0}^{T} \varphi(t)\left[\left\langle L \frac{d x}{d t}, w\right\rangle+\langle M(x), w\rangle\right] d t=\int_{0}^{T} \varphi(t)\langle u, w\rangle d t
$$




$$
\left\langle L\left(x(0)-x_{0}\right), w\right\rangle=0, \quad \forall w \in B, \forall \varphi \in L_{2}(0, T) .
$$

Theorem 1. [11] For any $x_{0} \in B, T \in \mathbb{R}_{+}, u \in L_{q}\left(0, T ; B^{*}\right)$ there exists a unique solution $x \in X$ of problem (2).

Definition 2. A pair $(\tilde{x}, \tilde{u}) \in X \times U_{a d}$ is called a solution of optimal control problem (1), (2), if

$$
J(\tilde{x}, \tilde{u})=\inf J(x, u),
$$

where pairs $(x, u) \in X \times U_{a d}$ satisfy (2) in the sense of Definition 1; a vector function $\tilde{u}$ is called an optimal control.

Theorem 2. [11] For any $x_{0} \in B, T \in \mathbb{R}_{+}$there exists a solution of optimal control problem (1), (2).

Now consider the optimal control problem for Boussinesq model (1), (5) - (7). Let $\Omega \subset \mathbb{R}^{n}$ be a bounded domain with boundary of class $C^{\infty}$. Suppose $H=W_{2}^{-1}(\Omega), A=$ $L_{2}(\Omega), B=L_{p}(\Omega)$. Define scalar product in $H$ by formula

$$
\langle x, y\rangle=\int_{\Omega} x \tilde{y} d s \forall x, y \in H,
$$

where $\tilde{y}$ is a generalized solution of homogeneous Dirichlet problem for Laplace operator $(-\Delta)$ in domain $\Omega$. Let $B^{*}=\left(L_{p}(\Omega)\right)^{*}$ and $A^{*}=\left(L_{2}(\Omega)\right)^{*}$ be conjugate respect to duality (11) of the space. For thus defined $A^{*}$ and $B^{*}$, there are dense and continuous embeddings (8). Denote a sequence of eigenfunctions of homogeneous Dirichlet problem for Laplace operator $(-\Delta)$ in domain $\Omega$ by $\left\{\varphi_{k}\right\}$ and a corresponding sequence of eigenvalues enumerated in nondecreasing order with respect to their multiplicities by $\left\{\lambda_{k}\right\}$. Define operators $L$ and $M$ in the following way:

$$
\begin{aligned}
& \langle L x, y\rangle=\int_{\Omega}(\lambda x \tilde{y}+x y) d s, \quad x, y \in A \\
& \langle M(x), y\rangle=\int_{\Omega}|x|^{p-2} x y d s, \quad x, y \in B .
\end{aligned}
$$

Lemma 1. [26] (i) For any $\lambda \geq-\lambda_{1}$ operator $L \in L\left(A ; A^{*}\right)$ is self-adjoint, fredholm and nonnegative defined, and orthonormal set $\left\{\varphi_{k}\right\}$ of its functions forms a basis of space $H$.

(ii) Operator $M \in C^{1}\left(B ; B^{*}\right)$ is s-monotone and $p$-coercive.

System $\left\{\varphi_{k}\right\}$ due to embeddings (8) forms a basis in space $W_{2}^{-1}(\Omega)$. Choose in $W_{2}^{-1}(\Omega)$ orthonormal system $\left\{\varphi_{i}\right\}$ such that $\operatorname{span}\left\{\varphi_{1}, \varphi_{2}, \ldots, \varphi_{l}\right\}=\operatorname{ker} L$, where $l=\operatorname{dim} \operatorname{ker} L$. Construct Galerkin approximations of problem (5) - (7) solution in the form (10), where coefficients $a_{i}=a_{i}(t), i=1, \ldots, m$, are defined by system of equations

$$
\int_{\Omega}\left(\lambda x_{t}^{m} \tilde{\varphi}_{i}+x_{t}^{m} \varphi_{i}+\alpha\left|x^{m}\right|^{p-2} x^{m} \varphi_{i}\right) d s=\int_{\Omega} u^{m} \tilde{\varphi}_{i} d s, i=1, \ldots, m,
$$

and Showalter - Sidorov conditions

$$
\int_{\Omega}\left[\lambda\left(x_{m}(s, 0)-x_{0}(s)\right) \tilde{\varphi}_{i}+\left(x_{m}(s, 0)-x_{0}(s) \varphi_{i}(s)\right] d s=0 .\right.
$$


Set of equations (12) is a degenerate system of ordinary differential equations. Suppose $T_{m} \in \mathbb{R}_{+}, T_{m}=T_{m}\left(x_{0}\right), B^{m}=\operatorname{span}\left\{\varphi_{1}, \varphi_{2}, \ldots, \varphi_{m}\right\}$.

Lemma 2. [26] For any $x_{0} \in L_{p}(\Omega)$ and $m>l$ there exists a unique local solution $x^{m} \in C^{r}\left(0, T_{m} ; B^{m}\right)$ of problem (12), (13).

Construct a set

$$
\operatorname{coim} L=\left\{\begin{array}{c}
L_{p}(\Omega), \text { если } \lambda>-\lambda_{1} ; \\
\left\{x \in L_{p}(\Omega):\left\langle x, \varphi_{1}\right\rangle=0\right\}, \text { если } \lambda=-\lambda_{1},
\end{array}\right.
$$

and a space

$$
X=\left\{x \mid x \in L_{\infty}(0, T ; \operatorname{coim} L) \cap L_{p}\left(0, T ; L_{p}(\Omega)\right), \frac{d x}{d t} \in L_{2}(0, T ; \operatorname{coim} L) .\right.
$$

Definition 3. A weak generalized solution of equation (5) is a function $x \in X$, which satisfies the condition:

$$
\begin{aligned}
& \int_{0}^{T} \varphi(t)\left[\int_{\Omega}\left(\lambda x_{t} \tilde{w}+x_{t} w+\alpha|x|^{p-2} x w\right) d s\right] d t=\int_{0}^{T}\left[\varphi(t) \int_{\Omega} u \tilde{w} d s\right] d t \\
& \forall w \in L_{p}(\Omega), \forall \varphi \in L_{2}(0, T) .
\end{aligned}
$$

Theorem 3. [26] Suppose $p \geq \frac{2 n}{n+2}, \lambda \geq-\lambda_{1}$, then for any $x_{0} \in B, T \in \mathbb{R}_{+}, u \in$ $L_{q}\left(0, T ; B^{*}\right)$ there exists a unique solution $x \in X$ of problem (5) - (7).

Now consider the optimal control problem for generalized Boussinesq filtration model. In cylinder $Q_{T}=\Omega \times(0, T)$ consider optimal control problem

$$
J(x, u)=\alpha\left\|x-z_{d}\right\|_{L_{p}(Q)}^{p}+\beta \int_{0}^{T}\|u\|_{\left(L_{p}(\Omega)\right)^{*}}^{q} d t \rightarrow \inf , \alpha+\beta=1 .
$$

Choose a closed and convex set $U_{a d} \subset L_{q}\left(0, T ;\left(L_{p}(\Omega)\right)^{*}\right)$.

Theorem 4. [26] Suppose $p \geq \frac{2 n}{n+2}, \lambda \geq-\lambda_{1}$, then for any $x_{0} \in B$ there exists an optimal control in the problem (5) - (7).

\section{Algorithm of the Numerical Method}

Our goal is to find the approximate solution of optimal control problem (1) by the solutions of problem (2). In [25] we consider an algorithm of the numerical method for solving the optimal control problem for a semilinear Sobolev-type equation, which is based on the Galerkin method together with the decomposition method. However, the algorithm may be applied only to the equations with linear component. Let us propose an algorithm of the numerical method, which is based on both the modified Galerkin method and the method of multistep coordinate descent. The algorithm allows to avoid such restrictions.

Let $\sigma(L)$ be spectrum of operator $L$. Because of the properties of operator $L$, its spectrum $\sigma(L)$ is non-negative, discrete, finite multiplicity and thickens only to $+\infty$. Let $\left\{\lambda_{i}\right\}$ be a set of the eigenvalues, which are numbered in non-decreasing order according to multiplicity. Let $\left\{\varphi_{i}\right\}$ be a set of the corresponding eigenfunctions which are orthonormal 
with respect to the scalar product $\langle\cdot, \cdot>$ from $H$. They form an orthonormal basis in space $H$.

Let us find an approximate solution of problem as the sum 10 where $m \in \mathbb{N}, m>l$, $l=\operatorname{dimker} L$ (to take into account the effects of the reduced equation). Represent the right side of equation (2) as

$$
u^{m}(s, t)=\sum_{i=1}^{m}<u(s, t), \varphi_{i}(s)>\varphi_{i}(s)=\sum_{i=1}^{m} u_{i}(t) \varphi_{i}(s) .
$$

We substitute Galerkin sums (10) and (15) to equation (2). So we get a system of nonlinear differential equations (3). Note that system (3) consists of non-linear equations. Therefore unknowns $a_{i}(t)$ can not be express through control $u_{i}(t)$. It imposes additional difficulties for finding a solution of optimal control problem (1), (2). Substitute Galerkin sums (10) and (15) in the objective functional and get a definite integral of the function, depending on the unknowns $a_{i}(t)$ и $u_{i}(t), i=1, \ldots, m$, by interval $[0, T]$. Let us search unknowns $u_{i}(t), i=1, \ldots, m$, in the form

$$
u_{i}(t, N)=\sum_{n=0}^{N} b_{i n} t^{n}
$$

choosing coefficients $b_{i n}$ such that functions $u_{i}(t, N)$ minimize functional (9). Control coefficients $b_{\text {in }}$ form matrix $\mathcal{B}$ having size of $m \times(N+1)$. Depending on parameter $\lambda$, equations of system (5) can be differential or algebraic.

Consider these cases.

(i) Let $\lambda \notin \sigma(L)$. In this case all equations of system (3) are ordinary differential equations of the first order. We find $m$ initial conditions in the following way. Multiply conditions (4) on eigenfunctions $\varphi_{i}(s), i=1, \ldots, m$, scalar in $H$.

(ii) Let $\lambda \in \sigma(L)$. In this case the equations of system (3) with numbers $1_{1}, \ldots, 1_{l}$ are algebraic, and the rest ones are differential. From the Showalter - Sidorov condition, we find $m-l$ initial conditions in the following way. Multiply conditions (4) on eigenfunctions $\varphi_{i}(s), i=1, \ldots, m$, scalar in $H$.

An algorithm of finding the approximate solution of problem (1), (2) is reduced to six steps. The first 4 steps are based on projection Galerkin method and similar to the appropriate steps in the algorithm in [25]. The subsequent steps allow to minimize objective functional and are based on a modification method of the multi-step coordinate descent with memory, which is proposed in [23].

Step 1. Find eigenvalues and eigenfunctions of operator $L$, that is, the solution of problem $\langle L \varphi, v\rangle=\lambda\langle\varphi, v\rangle$ with appropriate boundary conditions.

Step 2. Find number $m$ such that from $m$ we can calculate the approximate solution using the condition: $m>l, l=\operatorname{dim} \operatorname{ker} L$.

Step 3. Check by specified parameter $\lambda$ : the mathematical model corresponds to degenerate case or to non-degenerate case.

Step 4. Depending on cases (i), (ii), generate a system of differential-algebraic equations for the unknowns $a_{i}(t), i=1, \ldots, m$, and $b_{i n}, i=1, \ldots, m, n=1, \ldots, N$, with the corresponding initial conditions. 
Step 5. Generate an objective functional. Find minimum of the functional and minimum point $u^{m}=\operatorname{col}\left(\sum_{n=0}^{N} b_{1 n} t^{n}, \ldots, \sum_{n=0}^{N} b_{m n} t^{n}\right)$ using the descent method. Finding unknowns $b_{i n}$ is reduced to the following sub-steps.

Step 5.1. Set values of parameters required for the calculation. They are a maximum step $h_{\max }>0$, a minimum step $h_{\min }>0$, a value of admissible error $\varepsilon>0$ of cost functional calculation, a value of change step $r \in(0,1)$, an initial value of control matrix $\mathcal{B}$.

Step 5.2. Let $\rho$ be an iteration number of the main calculation $(\rho=0, \ldots) ; \hat{b}_{i n}^{\rho}$ be coefficients of function $u_{i}(t)$, forming matrix $n \times(N+1)$ at $\rho$-th step; $J_{\rho}$ be approximate value of the quality functional, calculated at $\rho$-th step. In each row of array $\mathcal{B}$, from the first and sequentially to the last one, we define coefficient $\hat{b}_{i n}^{\rho}$ to be change as follows. Calculate the value of functional $J_{\rho}$ for given initial matrix $\mathcal{B}$. Substitute $\mathcal{B}$ in the right part of system of equations (3). On the basis of Euler method, we numerically find unknowns $a_{i}\left(\tau_{j}\right), i=1, \ldots, m, j=0, \ldots, n$. Using Gauss quadrature formula in appropriate nodes $\tau_{j}, j=0, \ldots, n$, we numerically calculate the value of functional $J_{\rho}$. After that, we use the method of multistep coordinate descent with memory [23] and change elements $b_{1 j}$ with an initial value of all other elements in order to define a value $\hat{b}_{1 j}$ such that the obtained value $J_{1 j}$ is minimal. Denote corresponding element by $\hat{b}_{1 j}$. Note that only $\hat{b}_{1 j}$ should be changed. Then we conduct a cycle by the elements of the second row and so on. The result is a new array. Each line of such new array contains a unique changed element. Such new array is used in the main calculation. For each row, we fix value $\Delta_{i}$ of the step, which provides the minimum value of the quality functional. In the next iteration, elements of $i$-th row are change from $\Delta_{i}$-th number (not from $h_{\max }$-th). It significantly increases the speed of calculations.

Step 5.3. Calculate a value of functional $J_{\rho}$ by obtained matrix $\mathcal{B}$.

Step 5.4. Check that the stop condition

$$
\left|J_{k}\left(\hat{b}_{i j}^{\rho}\right)-J_{k}\left(\hat{b}_{i j}^{\rho-1}\right)\right|<\varepsilon
$$

is hold. If it is hold, then we set $b_{i j}=\hat{b}_{i j}^{\rho}, i=\overline{1, n}, j=\overline{0, N}$ and $\hat{J}=J_{\rho}$.

Step 6 . In given points $\tau_{j} \in[0, T]$ for given values $b_{i n}$ we calculate the value of functional $J\left(x^{m}, u^{m}\right)$. Thus, value $u^{m}(s, t)$ is found. Calculate values $a_{i}(t)$ and $x^{m}(s, t)$.

\section{Numerical Study of Model to Regulate the Distribution of the Filtered Liquid Free Surface Movement Speed Potential}

In cylinder $Q_{T}=(0, l) \times(0, T), T>0$ we consider a generalized filter Boussinesq model (5), (6) with initial Showalter - Sidorov condition (7). Our goal is to find the approximate solution of optimal control problem (1) by solutions of problem $(5)-(7)$, where the cost functional is given as

$$
J(x, u)=\beta \int_{0}^{T} \int_{0}^{l}\left|x(s, t)-z_{d}(s, t)\right|^{p} d s d t+(1-\beta) \int_{0}^{T} \int_{0}^{l}|u|^{q} d s d t,
$$


where $\frac{1}{p}+\frac{1}{q}=1$. In view of the proposed method, we search approximate solution $\tilde{x}(s, t)$ as the sum

$$
\tilde{x}(s, t)=x^{m}(s, t)=\sum_{i=1}^{m} a_{i}(t) \varphi_{i}(s), m>1,
$$

where $\left\{\varphi_{i}\right\}$ is a set of all solutions of Sturm - Liouville problem on eigenvalues

$$
\begin{gathered}
(\lambda-\Delta) X(s)=0, s \in(0, l) ; \\
X(0)=X(l)=0 .
\end{gathered}
$$

Such spectral problem is solvable for a countable set of eigenvalues $\lambda_{i}$, and functions $\left\{\varphi_{i}\right\}$ form orthonormal system (with weight $\frac{2}{l}$ ) of functions

$$
\frac{2}{l} \int_{0}^{l} \varphi_{i} \varphi_{l} d s=<\varphi_{i}, \varphi_{l}>=\left\{\begin{array}{l}
1, l=i \\
0, l \neq i
\end{array}\right.
$$

where $\varphi_{i}=\varphi_{i}(s)=\sqrt{\frac{2}{l}} \sin \left(\frac{\pi i s}{l}\right)$, a $\lambda_{i}=-i^{2}$. Represent the right side of equation (5) in the form

$$
\tilde{u}(s, t)=\sum_{i=1}^{m}<u(s, t), \varphi_{i}(s)>\varphi_{i}(s)=\sum_{i=1}^{m} u_{i}(t) \varphi_{i}(s) .
$$

Let us search unknowns $u_{i}(t), i=r, \ldots, m$ in the form

$$
u_{i}(t, N)=\sum_{n=0}^{N} b_{i n} t^{n}
$$

choosing coefficients $b_{i n}$ such that functions $u_{i}(t, N)$ provides minimum to functional (16).

Sample. Consider problem (1), (5) - (7) in case of $\lambda=-1, p=4, l=\pi, T=1$, $\beta=\frac{1}{2}, m=5, N=5$, with initial state

$$
x_{0}(s)=2 \sin (s)+\sin (2 s)+\sin (5 s)
$$

and desired system state

$$
z_{d}(s, t)=\frac{1}{4} \sin s+\left(t^{2}+1\right) \sin (2 s)+0,6 t^{3} \sin (3 s)+2 t \sin (4 s)+\sin (5 s) .
$$

The state should be achieved as a result of the numerical solution with the least of control costs.

The result of programm performance is following. We find the control coefficients (Table 1). They provide functional value $J=3,971911$. For obtained control coefficients, we find the numerical solution of problem (5) - (7) (Table 2). A diagrams of approximate solution $\tilde{x}(s, 1)$ and desired state $z_{d}(s, 1)$ at moment $t=1$ are shown in Figure. 
Table 1

\begin{tabular}{|l|l|l|l|l|l|}
\hline$b_{10}=0$ & $b_{11}=0,39321$ & $b_{12}=0$ & $b_{13}=0$ & $b_{14}=0,32853$ & $b_{15}=-0,02342$ \\
\hline$b_{20}=0$ & $b_{21}=0,6752$ & $b_{22}=0$ & $b_{23}=0$ & $b_{24}=-0,60952$ & $b_{25}=1,6272$ \\
\hline$b_{30}=0,09648$ & $b_{31}=0$ & $b_{32}=0$ & $b_{33}=0$ & $b_{34}=0$ & $b_{35}=1,32086$ \\
\hline$b_{40}=-0,05225$ & $b_{41}=0,37955$ & $b_{42}=0$ & $b_{43}=0$ & $b_{44}=0$ & $b_{45}=0$ \\
\hline$b_{50}=0$ & $b_{51}=0$ & $b_{52}=0$ & $b_{53}=0$ & $b_{54}=0$ & $b_{55}=3,42518$ \\
\hline
\end{tabular}

Table 2

\begin{tabular}{|l|l|l|l|l|l|}
\hline$t$ & $a_{1}(t)$ & $a_{2}(t)$ & $a_{3}(t)$ & $a_{4}(t)$ & $a_{5}(t)$ \\
\hline 0 & 0,388145 & 1,79222 & 0 & 0 & 3,22603 \\
\hline 0,2 & 0,337140 & 0,895050 & 0,0966660 & 0,0292608 & 2,14099 \\
\hline 0,4 & 0,542735 & 0,804680 & 0,28903 & 0,199218 & 1,90507 \\
\hline 0,6 & 0,763540 & 0,898925 & 0,532845 & 0,432169 & 1,89978 \\
\hline 0,8 & 0,952825 & 1,08606 & 0,839645 & 0,752255 & 2,09191 \\
\hline 1,0 & 0,985030 & 1,34000 & 1,24176 & 1,22444 & 2,59138 \\
\hline
\end{tabular}

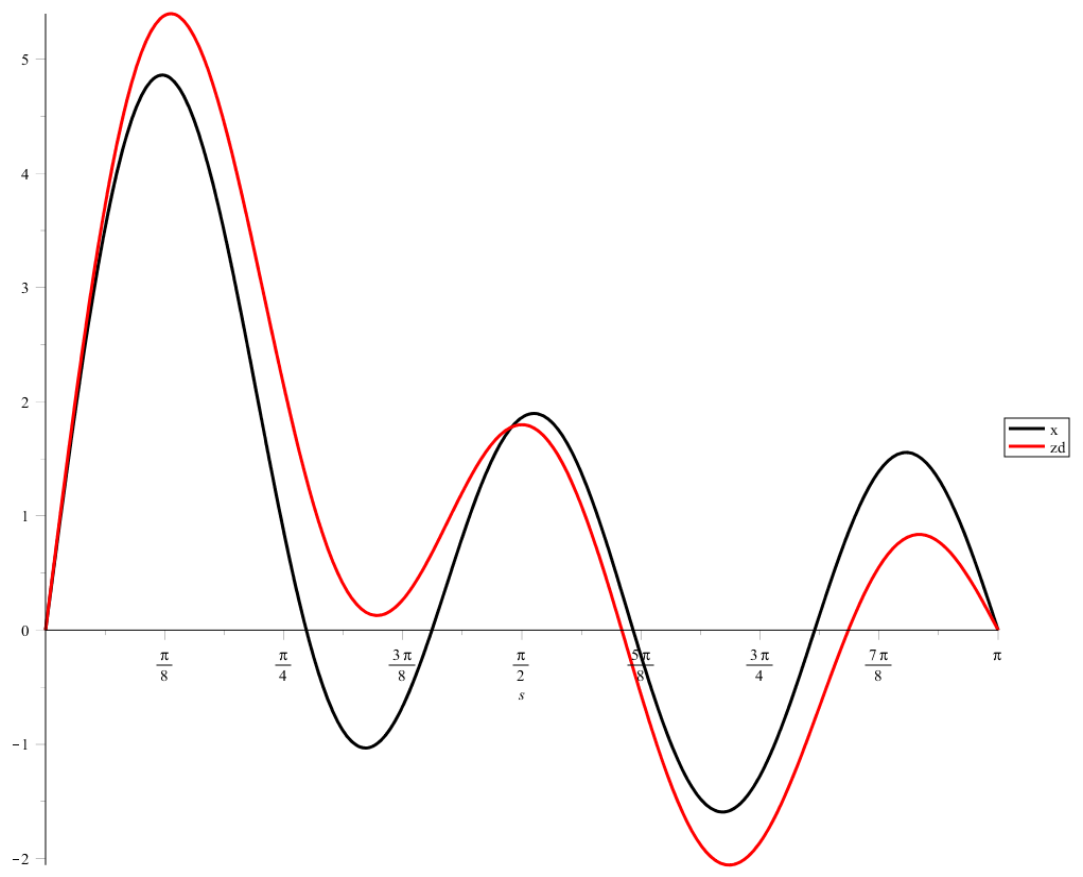

Diagram of problem (1), (5) - (7) numerical solution at moment $t=1$ 


\section{References}

1. Showalter R.E. The Sobolev Equation. Applicable Analysis, 1975, vol. 5, no. 1, pp. 15-22; vol. 5, no. 2, pp. 81-89.

2. Sviridyuk G. A. The Cauchy Problem for a Linear Operator Equation of Sobolev Type with a Nonpositive Operator Multiplying the Derivative. Differentsial'nye Uravneniya, 1987, vol. 23, no. 10, pp. 1823-1826. (in Russian)

3. Oskolkov A.P. Nonlocal Problems for One Class of Nonlinear Operator Equations that Arise in the Theory of Sobolev Type Equations. Journal of Mathematical Sciences, 1993, vol. 64, issue 1, pp. 724-736.

4. Sviridyuk G.A., Fedorov V.E. Linear Sobolev Type Equations and Degenerate Semigroups of Operators. Utrecht, Boston, Köln, VSP, 2003. 216 p.

5. Al'shin A.B., Korpusov M.O., Sveshnikov A.G. Blow-up in Nonlinear Sobolev-Type Equations. Berlin, N.Y., de Gruyter, 2011.

6. Zamyshlyaeva A.A. The High-Order Sobolev Type Model. Bulletin of the South Ural State University. Series: Mathematical Modelling, Programming and Computer Software, 2014, vol. 7, no. 2, pp. 5-28. doi: 10.14529/mmp140201 (in Russian)

7. Zagrebina S.A. A Multipoint Initial-Final Value Problem for a Linear Model of Plane-Parallel Thermal Convection in Viscoelastic Incompressible Fluid. Bulletin of the South Ural State University. Series: Mathematical Modelling, Programming and Computer Software, 2014, vol. 7, no. 3, pp. 5-22. doi: 10.14529/mmp140301 (in Russian)

8. Keller A.V., Zagrebina S.A. Some Generalizations of the Showalter - Sidorov Problem for Sobolev-Type Models. Bulletin of the South Ural State University. Series: Mathematical Modelling, Programming and Computer Software, 2015, vol. 8, no. 2, pp. 5-23. doi: 10.14529/mmp150201 (in Russian)

9. Sagadeeva M.A., Hasan F.L. Bounded Solutions of Barenblatt - Zheltov - Kochina Model in Quasi-Sobolev Spaces. Bulletin of the South Ural State University. Series: Mathematical Modelling, Programming and Computer Software, 2015, vol. 8, no. 4, pp. 138-144. doi: 10.14529/mmp150414 (in Russian)

10. Sviridyuk G.A., Efremov A.A. Optimal Control of Sobolev Type Linear Equations with Relativity p-Sectorial Operators. Differential Equations, 1995, vol. 31, no. 11, pp. $1882-1890$.

11. Sviridyuk G.A., Manakova N.A. Phase Space of the Cauchy - Dirichlet Problem for the Oskolkov Equation of Nonlinear Filtration. Russian Mathematics, 2003, vol. 47, no. 9 , pp. 33-38.

12. Zamyshlyaeva A.A., Tsyplenkova O.N. Optimal Control of Solutions of the Showalter - Sidorov - Dirichlet Problem for the Boussinesq - Love Equation. Differential Equations, 2013, vol. 49, no. 11, pp. 1356-1365. doi: 10.1134/S0012266113110049

13. Bogatyreva E.A. The Start Control and Final Observation Problem for a QuasiLinear Sobolev Type Equation. Bulletin of the South Ural State University. Series: Mathematics. Mechanics. Physics, 2015, vol. 7, no. 4, pp. 5-10. 
14. Manakova N.A., Gavrilova O.V. Optimal Control for a Mathematical Model of Nerve Impulse Spreading. Bulletin of the South Ural State University. Series: Mathematical Modelling, Programming and Computer Software, 2015, vol. 8, no. 4, pp. 120-126. doi: 10.14529/mmp150411 (in Russian)

15. Shestakov A.L., Sviridyuk G.A. Optimal Measurement of Dynamically Distorted Signals. Bulletin of the South Ural State University. Series: Mathematical Modelling, Programming and Computer Software, 2011, no. 17 (234), issue 8, pp. 70-75. (in Russian)

16. Keller A.V., Sagadeeva M.A. The Optimal Measurement Problem for the Measurement Transducer Model with a Deterministic Multiplicative Effect and Inertia. Bulletin of the South Ural State University. Series: Mathematical Modelling, Programming and Computer Software, 2014, vol. 7, no. 1, pp. 134-138. doi: 10.14529/mmp140111 (in Russian)

17. Sviridyuk G.A., Zagrebina S.A. The Showalter - Sidorov Problem as a Phenomena of the Sobolev Type Equations. The Bulletin of Irkutsk State University. Series: Mathematics, 2010, vol. 3, no. 1, pp. 104-125. (in Russian)

18. Manakova N.A., Sviridyuk G.A. Nonclassical Equations Of Mathematical Physics. Phase Space Of Semilinear Sobolev Type Equations Bulletin of the South Ural State University. Series: Mathematics. Mechanics. Physics, 2016, vol. 8, no. 3, pp. 31-51. doi: 10.14529/mmph160304

19. Lions J.-L. Contrôle optimal de systémes gouvernés par des équations aux dérivées partielles. Paris, Dunod, 1968.

20. Sviridyuk G.A., Sukacheva T.G. Galerkin Approximations of Singular Nonlinear Equations of Sobolev Type. Soviet Mathematics (Izvestiya VUZ. Matematika), 1989, no. 10 , pp. $56-59$.

21. Zamyshlyaeva A.A., Muravyev A.S. Computational Experiment for One Mathematical Model of Ion-Acoustic Waves. Bulletin of the South Ural State University. Series: Mathematical Modelling, Programming and Computer Software, 2015, vol. 8, no. 2, pp. 127-132. doi: 10.14529/mmp150211

22. Bogatyreva E.A., Manakova N.A. Numerical Simulation of the Process of Nonequilibrium Counterflow Capillary Imbibition. Computational Mathematics and Mathematical Physics, 2016, vol. 56, no. 1, pp. 132-139. doi: 10.1134/S0965542516010085

23. Keller A.V., Nazarova E.I. Optimal Measuring Problem: the Computation Solution, the Program Algorithm. The Bulletin of Irkutsk State University. Series: Mathematics, 2011, vol. 4, no. 3, pp. 74-82.(in Russian)

24. Keller A.V., Sagadeeva M.A. [The Numerical Solution of Optimal and Hard Control for Nonstationary System of Leontiev Type]. Belgorod State University Scientific Bulletin. Mathematics, Physics, 2013, vol. 32, no. 19, pp. 57-66. (in Russian)

25. Manakova N.A. Algorithm for Numerical Method of Solution of the Optimal Control Problem for Semilinear Sobolev Type Models on Basis of Decomposition Method. Journal of Computational and Engineering Mathematics, 2015, vol. 2, no. 3, pp. 43-59. 
26. Manakova N.A. [Optimal Control Problem for the Generalized Boussinesq Filtration Equation]. Vestnik Magnitogorskogo gosudarstvennogo universiteta. Seria: Matematika [Bulletin of Magnitogorsk State University. Series: Mathematics], 2005, issue 8, pp. 113-122. (in Russian)

27. Dzektser E.S. [The Generalization of the Equations of Motion of Groundwater]. Dokl. Akad. Nauk SSSR, 1972, no. 5, pp. 1031-1033. (in Russian)

Natalia A. Manakova, DSc (Math), Professor, Department of Equation of Mathematical Physics, South Ural State University (Chelyabinsk, Russian Federation), manakovana@susu.ru.

Received September 10, 2016

УДК 517.9

DOI: $10.14529 /$ jcem160405

\title{
О МОДИФИЦИРОВАННОМ МЕТОДЕ МНОГОШАГОВОГО ПОКООРДИНАТНОГО СПУСКА ЗАДАЧИ ОПТИМАЛЬНОГО УПРАВЛЕНИЯ ДЛЯ ПОЛУЛИНЕЙНОЙ МОДЕЛИ СОБОЛЕВСКОГО ТИПА
}

\section{Н.А. Манакова}

\begin{abstract}
В работе описан численный метод решения задачи оптимального управления для полулинейной модели соболевского типа, основанный на модифицированном проекционном методе Галеркина и методе многошагового покоординатного спуска с памятью. Необходимость построения новых численных методов решения нелинейных задач оптимального управления связана с большим количеством приложений и трудностью нахождения их аналитических решений. На основе достаточных условий существования оптимального управления решениями задачи Шоуолтера - Сидорова для полулинейного уравнения соболевского типа с $s$-монотонным и $p$-коэрцитивным оператором численно исследована математическая модель регулироования распределения потенциала скорости движения свободной поверхности фильтрующейся жидкости. Приведены результаты вычислительного эксперимента, демонстрирующие работу предложенного численного метода.

Ключевые слова: уравнения соболевского типа; задача оптимального управления; численное решение; метод Галеркина; метод многошагового покоординатного спуска.
\end{abstract}

\section{Литература}

1. Showalter, R.E. The Sobolev Equation / R.E. Showalter // Applicable Analysis. 1975. - V. 5, № 1. - P. 15-22; V. 5, №. 2. - P. 81-89.

2. Свиридюк, Г.А. Задача Коши для линейного операторного уравнения типа Соболева с неположительным оператором при производной / Г.А. Свиридюк // Дифференциальные уравнения. - 1987. - Т. 23, № 10. - С. 1823-1826.

3. Осколков, А.П. Нелокальные задачи для одного класса нелинейных операторных уравнений, возникающих в теории уравнений типа С.Л. Соболева / А.П. Осколков // Записки научных семинаров ЛОМИ. - 1991. - Т. 198. - С. 31-48. 
4. Sviridyuk, G.A. Linear Sobolev Type Equations and Degenerate Semigroups of Operators / G.A. Sviridyuk, V.E. Fedorov. - Utrecht; Boston; Köln: VSP, 2003.

5. Al'shin, A.B. Blow-up in Nonlinear Sobolev-Type Equations / A.B. Al'shin, M.O. Korpusov, A.G. Sveshnikov. - Berlin, N.-Y.: de Gruyter, 2011.

6. Замышляева, А.А. Математические модели соболевского типа высокого порядка / А.А. Замышляева // Вестник ЮУрГУ. Серия: Математическое моделирование и программирование. - 2014. - Т. 7, № 2. - С. 5-28.

7. Zagrebina, S.A. A Multipoint Initial-Final Value Problem for a Linear Model of PlaneParallel Thermal Convection in Viscoelastic Incompressible Fluid / S.A. Zagrebina // Вестник ЮУрГУ. Серия: Математическое моделирование и программирование. 2014. - T. 7, № 3. - C. 5-22.

8. Келлер, А.В. Некоторые обобщения задачи Шоуолтера - Сидорова для моделей соболевского типа / А.В. Келлер, С.А. Загребина // Вестник ЮУрГУ. Серия: Математическое моделирование и программирование. - 2015. - Т. 8, № 2. - С. 5-23.

9. Сагадеева, М.А. Ограниченные решения модели Баренблатта - Желтова - Кочиной в квазисоболевых пространствах / М.А. Сагадеева, Ф.Л. Хасан // Вестник ЮУрГУ. Серия: Математическое моделирование и программирование. - 2015. T. 8, № 4. - C. 138-144.

10. Свиридюк, Г.А. Оптимальное управление линейными уравнениями типа Соболева с относительно p-секториальными операторами / Г.А. Свиридюк, А.А. Ефремов // Дифференциальные уравнения. - 1995. - Т. 31, № 11. - С. 1912-1919.

11. Свиридюк, Г.А. Фазовое пространство задачи Коши - Дирихле для уравнения Осколкова нелинейной фильтрации / Г.А. Свиридюк, Н.А. Манакова // Известия вузов. Математика. - 2003. - № 9. - С. 36-41.

12. Замышляева, А.А. Оптимальное управление решениями задачи Шоуолтера Сидорова - Дирихле для уравнения Буссинеска - Лява / А.А. Замышляева, О.Н. Цыпленкова // Дифференциальные уравнения. - 2013. - Т. 49, № 11. C. $1390-1398$.

13. Богатырева, Е.А. Задача стартового управления и финального наблюдения для одного квазилинейного уравнения соболевского типа / Е.А. Богатырева // Вестник ЮУрГУ. Серия: Математика. Механика. Физика. - 2015. - Т. 7, № 4. - С. 5-10.

14. Манакова, Н.А. Оптимальное управление для одной математической модели распространения нервного импульса / Н.А. Манакова, О.В. Гаврилова // Вестник ЮУрГУ. Серия: Математическое моделирование и программирование. - 2015. T. 8, № 4. - C. 120-126.

15. Shestakov, A.L. Optimal Measurement of Dynamically Distorted Signals / A.L. Shestakov, G.A. Sviridyuk // Вестник ЮУрГУ. Серия: Математическое моделирование и программирование. - 2011. - № 17 (234), вып. 8. - С. 70-75.

16. Келлер, А.В. Задача оптимального измерения для модели измерительного устройства с детерминированным мультипликативным воздействием и инерционностью / А.В. Келлер, М.А. Сагадеева // Вестник ЮУрГУ. Серия: Математическое моделирование и программирование. - 2014. - Т. 7, № 1. - С. 134-138.

17. Свиридюк, Г.А. Задача Шоуолтера - Сидорова как феномен уравнений соболевского типа / Г.А. Свиридюк, С.А. Загребина // Известия Иркутского государственного университета. Серия: Математика. - 2010. - Т. 3, № 1. - С. 51-72. 
18. Свиридюк, Г.А. Неклассические уравнения математической физики. Фазовые пространства полулинейных уравнений соболевского типа / Г.А. Свиридюк, Н.А. Манакова // Вестник ЮУрГУ. Серия: Математика. Механика. Физика. 2016. - T. 8, № 3. - C. 31-51.

19. Лионс, Ж.-Л. Управление сингулярными распределенными системами Ж.-Л. Лионс. - М.: Наука, 1987. - 367 с.

20. Свиридюк, Г.А. О галеркинских приближениях сингулярных нелинейных уравнений типа Соболева / Г.А. Свиридюк, Т.Г. Сукачева // Известия вузов. Математика. - 1989. - № 10. - С. 44-47.

21. Богатырева, Е.А. Численное моделирование процесса неравновесной противоточной капиллярной пропитки / Е.А. Богатырева, Н.А. Манакова // Журнал вычислительной математики и математической физики. - 2016. - Т. 56, № 1. C. $125-132$.

22. Замышляева, А.А. Вычислительный эксперимент для одной математической модели ионно-звуковых волн / А.А. Замышляева, А.С. Муравьев // Вестник ЮУрГУ. Серия: Математическое моделирование и программирование. - 2015. - Т. 8, № 2. - C. 127-132.

23. Келлер, А.В. Задача оптимального измерения: численное решение, алгоритм программы / А.В. Келлер, Е.И. Назарова // Известия Иркутского государственного университета. Серия: Математика. - 2011. - Т. 4, № 3. - С. 74-82.

24. Келлер, А.В. Численное решение задач оптимального и жесткого управления для одной нестационарной системы леонтьевского типа / А.В. Келлер, М.А. Сагадеева // Научные ведомости Белгородского государственного университета. Серия: Математика. Физика. - 2013. - Т. 32, № 19. - С. 57-66.

25. Manakova, N.A. Algorithm for Numerical Method of Solution of the Optimal Control Problem for Semilinear Sobolev Type Models on Basis of Decomposition Method / N.A. Manakova // Journal of Computational and Engineering Mathematics. - 2015. V. 2, № 3. - P. 43-59.

26. Манакова Н.А. Задача оптимального управления для обобщенного фильтрационного уравнения Буссинеска / Н.А. Манакова // Вестник МаГУ. Математика. Вып. 8. - Магнитогорск, 2005. - С. 113-122.

27. Дзекцер, Е.С. Обобщение уравнения движения грунтовых вод / Е.С. Дзекцер // Доклады Академии наук СССР. - 1972. - Т. 202, № 5. - С. 1031-1033.

Манакова Наталья Александровна, доктор физико-математических наук, профессор, кафедра уравнений математической физики, Южно-Уральский государственный университет (г. Челябинск, Российская Федерация), manakovana@susu.ru.

Поступила в редакиию 10 сентября 2016 г. 